УДК 342.9:351.74 (477)

DOI https://doi.org/10.32837/pyuv.v2i3(28).374

F. I. IInapara

здобувач кафедри адліністративного права та процесу Харківського національного університету внутрішніх справ

\title{
НОРМАТИВНІ ЗАСАДИ ДІЯЛЬНОСТІ РЕГІОНАЛЬНОГО ДЕПАРТАМЕНТУ СОЦІАЛЬНОГО ЗАХИСТУ НАСЕЛЕННЯ: ПОРІВНЯЛЬНО-ПРАВОВИЙ АНАЛІЗ
}

Основними завданнями соціальної держави є створення умов для реалізації соціальних, культурних і економічних прав людини, сприяння самостійності і відповідальності кожної особи за свої дії, надання соціальної допомоги тим громадянам, які з незалежних від них обставин не можуть забезпечити достатній рівень життя для себе і своєї сім'ї. Метою реформ у сфері соціального захисту населення $€$ формування сучасної системи захисту прав та інтересів усіх соціальних груп на основі міжнародних норм і європейських стандартів. Протягом останніх років основну увагу уряду було зосереджено на відновленні зростання реальних доходів громадян через проведення комплексних реформ у сфері пенсійного забезпечення, соціальної підтримки населення. Основою таких реформ стали нормативно-правові акти, що покликані врегульовувати як уже сформовані правовідносини щодо соціального захисту населення, так і ті, що стали викликом сьогодення, зокрема впровадження інтегрованої моделі системи соціального захисту населення на рівні об'єднаних територіальних громад. У свою чергу, основою діяльності будь-якого органу публічної влади є правовий базис - нормативно-правові засади. Отже, ефективність роботи регіонального Департаменту соціального захисту населення потребує від держави своєчасного розроблення, ухвалення й оновлення нормативно-правових засад діяльності щодо захисту прав громадян на засадах загально-правових $\mathrm{i}$ спеціальних принципів.

На важливості вивчення нормативно-правових засад державних органів соціального захисту населення свого часу наголошували такі провідні вчені, як: В.Б. Авер' янов, О.М. Бандурка, О.В. Батанов, В.М. Вакуленко, Ю.П. Битяк, Л.К. Воронова, В.М. Гаращук, В.М. Горшеньов, С.М. Гусаров, P.А. Калюжний, І.Б. Коліушко, В.К. Колпаков, А.Т. Комзюк, В.В. Копєйчиков, Т.О. Коломоєць, А.Т. Комзюк, О.В. Кузьменко, В.Ф. Опришко, А.О. Селіванов, Ю.О. Тихомиров. Незважаючи на це, комплексних досліджень, присвячених аналізу нормативно-правових засад діяльності регіонального Департаменту соціального захисту населення, немає.

Мета статті - аналіз і окреслення змісту ключових нормативно-правових засад діяльності регіонального Департаменту соціального захисту населення з урахуванням різної юридичної сили правових актів.

Правову основу діяльності регіонального Департаменту соціального захисту населення становить досить розгалужена система як законодавчих, так і підзаконних нормативно-правових актів. Варто акцентувати увагу й на тому, що на офіційних сторінках органів публічної влади чи місцевого самоврядування систему законодавчих та підзаконних нормативно-правових актів визначають терміном «нормативні засади», рідше як «нормативно-правові засади». Варто констатувати, що на сторінках правової літератури згаданий термін не знайшов свого закріплення. Частіше тут уживаються терміни «правова основа», «правові засади». Так, Ю.М. Фролов асоціює нормативно-правові засади вищих навчальних закладів із сукупністю чинних нормативно-правових актів, що визначають мету, принципи, завдання, функції діяльності закладів вищої освіти, окреслюють їхній правовий статус [1, с. 1079]. Аналогічну думку висловлює й О.П. ЖЖарова [2, с. 49]. О.В. Звіздай уважає, що нормативно-правове поле функціонування та розвитку місцевого самоврядування в Україні складається 3 регуляторних актів різних рівнів, які можна умовно розділити на певні групи [3, с. 244]. Отже, маючи розуміння про синонімічність термінів "нормативні засади», «нормативно-правові засади», «правова основа», окреслимо рівні нормативних засад діяльності Департаменту соціального захисту населення з урахуванням юридичної сили правових актів, що врегульовують досліджувані відносини.

Перший рівень: Конституція України - закладає конституційні основи соціального захисту населення [4].

Другий рівень: закони України «Про місцеве самоврядування в Україні», «Про соціальні послуги», що регулюють засади місцевого самоврядування, повноваження органів та посадових осіб.

Третій рівень: нормативні акти Кабінету Мiністрів України (розпорядження та постанови), міністерств, відомств та інших центральних органів виконавчої влади, що ухвалюються на основі законів України і визначають порядок реалізації певних норм цих законів.

Четвертий рівень: нормативні акти місцевих державних адміністрацій та місцевих рад, що 
встановлюють особливості здійснення місцевого самоврядування в певній громаді (місцевий статут) та правила і процедури роботи органів місцевого самоврядування.

Ст. 46 Конституції України визначає, що громадяни мають право на соціальний захист, що включає право на забезпечення їх у разі повної, часткової або тимчасової втрати працездатності, втрати годувальника, безробіття з незалежних від них обставин, а також у старості та в інших випадках, передбачених законом. Це право гарантується загальнообов'язковим державним соціальним страхуванням завдяки страховим внескам громадян, підприємств, установ і організацій, а також бюджетним та іншим джерелам соціального забезпечення; створенням мережі державних, комунальних, приватних закладів для догляду за непрацездатними [4]. Отже, згідно з Конституцією України, громадяни мають право на соціальний захист, 3 яким кореспондується обов'язок держави щодо його забезпечення. Реалізація цього обов'язку здійснюється органами державної влади відповідно до їхніх повноважень. Тому важлива для розуміння природи інституту соціального захисту і місцевого самоврядування ч. 2 ст. 5 Конституції України: «Носієм суверенітету і єдиним джерелом влади в Україні є народ. Народ здійснює владу безпосередньо і через органи державної влади та місцевого самоврядування» [5, с. 31]. Безпосереднім органом, на який покладається проведення фінансової, цінової, інвестиційної та податкової політики; політики у сферах праці й зайнятості населення, соціального захисту, освіти, науки і культури, охорони природи, екологічної безпеки і природокористування, є Кабінет Мiністрів України. Ефективне здійснення Кабінетом Міністрів України цих повноважень є основою для вжиття ним заходів щодо забезпечення прав і свобод людини і громадянина, проведення політики у сфері соціального захисту. Отже, Кабінет Міністрів України видає нормативно-правові акти у сфері соціального захисту, керуючись законами України. Водночас Верховна Рада України як єдиний орган законодавчої влади в Україні виключно законами України закріплює права і свободи людини і громадянина, гарантії цих прав і свобод, основи соціального захисту [6].

Що ж стосується національного законодавства, то ст. 92 Основного закону встановлює чітку норму: виключно законами України визначаються основи соціального захисту, форми і види пенсійного забезпечення; засади регулювання праці і зайнятості, шлюбу, сім'ї, охорони дитинства, материнства, батьківства; виховання, освіти, культури й охорони здоров'я; екологічної безпеки (п. 6 ч. 1 згаданої статті) [4]. Окреслюючи нормативні засади діяльності регіонального Департаменту соціального захисту населення, варто за- значити, що одним із ключових є Закон України «Про соціальні послуги», який сьогодні має дві чинні редакції: від 19 червня 2003 р. [7] (втрачає свою чинність 1 січня 2020 р.; у новій редакції від 17 січня 2019 р. [8] (набирає чинності з 1 січня 2020 р.). Уважаємо за доцільне провести їх порівняльний аналіз.

Метою Закону України «Про соціальні послуги" $€$ визначення основних організаційних та правових засад надання соціальних послуг, спрямованих на профілактику складних життєвих обставин, подолання або мінімізацію їхніх негативних наслідків, особам/сім'ям, які перебувають у складних життєвих обставинах. Основними цілями варто визначити такі: профілактику, подолання та мінімізацію негативних наслідків складних життєвих обставин, під якими варто розуміти обставини, що негативно впливають на життя, стан здоров'я та розвиток особи, функціонування сім'ї, які особа/сім'я не може подолати самостійно (п. 15 ч. 1 ст. 1 Закону) [8]. Водночас варто зазначити досить широку сферу дії Закону: поширюється на громадян України, іноземців, осіб без громадянства, які на законних підставах проживають або перебувають на території України, зокрема на осіб, на яких поширюється дія Закону України «Про біженців та осіб, які потребують додаткового або тимчасового захисту» [9], i належать до вразливих груп населення.

Детальний аналіз змісту законів в обох редакціях дозволяє виокремити позитивні напрацювання у сфері соціального захисту населення, серед них нижчезазначені.

По-перше, чітко визначено на законодавчому рівні суб'єкти системи надання соціальних послуг: 1) уповноважені органи у сфері надання соціальних послуг; 2) отримувачі соціальних послуг; 3) надавачі соціальних послуг; 4) об'єднання працівників системи надання соціальних послуг; 5) об’єднання надавачів соціальних послуг; 6) об’єднання отримувачів соціальних послуг (ст. 8 Закону). У редакції Закону 2003 р. суб’єкти системи надання соціальних послуг поділялися виключно за принципом використання та розвитку всіх форм власності, вона складалася з державного та недержавного секторів.

По-друге, у ст. 10 Закону окреслено основні засади функціонування системи надання соціальних послуг [8]: 1) профілактичний характер; 2) відповідність соціальних послуг потребам осіб/ сімей, які належать до вразливих груп населення чи перебувають у складних життєвих обставинах; 3) різноманітність соціальних послуг, їх безперервність надання, що забезпечуються взаємодією суб'єктів системи надання соціальних послуг; 4) забезпечення державних гарантій у сфері надання соціальних послуг та демонополізації на ринку соціальних послуг; 5) рівність прав, обов’язків 
та відповідальності надавачів соціальних послуг державного і недержавного секторів.

По-третє, стали революційними положення ст. 15 Закону щодо Реєстру надавачів та отримувачів соціальних послуг, який створюється для забезпечення: 1) реалізації права особи/сім’ї на соціальні послуги; 2) профілактики складних життєвих обставин; 3) подолання складних життєвих обставин; 4) мінімізації негативних наслідків складних життєвих обставин; 5) обліку надавачів, отримувачів соціальних послуг та послуг, що їм надаються; 6) координації діяльності в системі надання соціальних послуг. Реєстр складається з розділів про надавачів соціальних послуг, окремо - про фізичних осіб, які надають соціальні послуги 3 догляду відповідно до цього Закону без здійснення підприємницької діяльності, та про отримувачів соціальних послуг [8].

По-четверте, удосконалено р. III - організація діяльності з надання соціальних послуг в частині їх класифікації. Відтепер соціальні послуги за типами поділяються на: 1) прості, що не передбачають надання постійної або систематичної комплексної допомоги (інформування, консультування, посередництво, надання притулку, представництво інтересів); 2) комплексні, що передбачають узгоджені дії фахівців з надання постійної або систематичної комплексної допомоги (догляд, виховання, спільне проживання, соціальний супровід, кризове втручання, підтримане проживання, соціальна адаптація, соціальна інтеграція та реінтеграція; 3) комплексні спеціалізовані соціальні послуги, що надаються певній категорії отримувачів соціальних послуг (ВІЛ-інфікованим особам, особам із залежністю від психотропних речовин, особам, які постраждали від торгівлі людьми, біженцям, особам із психічними розладами та іншим); 4) допоміжні, що надаються у вигляді натуральної допомоги (продукти харчування, предмети і засоби особистої гігієни, санітарногігієнічні засоби для прибирання, засоби догляду, одяг, взуття, інші предмети першої необхідності, організація харчування, забезпечення паливом) $\mathrm{i}$ технічних послуг [8]. Ця класифікація не є вичерпною та наведена з метою підсилення наукового припущення щодо своєчасності та нагальності ухвалення нової редакції досліджуваного Закону.

По-п'яте, на основі державного стандарту соціальних послуг деталізовано порядок їх надання, що проявляється в їх здійсненні шляхом ведення випадку, що включає такі етапи: 1) аналіз заяви/ звернення про надання соціальних послуг, повідомлення про осіб/сім’ї, які перебувають у складних життєвих обставинах або в ситуаціях, що загрожують життю чи здоров'ю особи; 2) оцінювання потреб особи/сім’ї в соціальних послугах; 3) ухвалення рішення про надання соціальних послуг з урахуванням індивідуальних потреб осо- би/сім’ї; 4) розроблення індивідуального плану надання соціальних послуг; 5) укладення договору про надання соціальних послуг; 6) виконання договору про надання соціальних послуг та індивідуального плану надання соціальних послуг; 7) здійснення моніторингу надання соціальних послуг і оцінки їхньої якості.

Поряд із наведеним убачається й негативна тенденція до оптимізації нового законодавства в частині відповідальності за порушення вимог про соціальні послуги. Так, редакція Закону від 2019 р. встановлює, що особи, винні в бездіяльності в організації надання соціальних послуг, порушенні вимог законодавства про соціальні послуги, несуть відповідальність згідно із законом. У свою чергу, Закон від 2003 р. чітко визначав види юридичної відповідальності: особи, винні в порушенні законодавства про соціальні послуги, несуть цивільно-правову, адміністративну або кримінальну відповідальність згідно із законами України [7].

Резюмуючи зазначені вище тези щодо аналізу Закону України «Про соціальні послуги» у редакціях від 2003 р. та 2019 р., убачається можливим дійти висновку про всебічний розвиток зазначеного нормативно-правового акта шляхом деталізації ключових положень. Наведене, безумовно, є відображенням реформ, які відбуваються в житті країни.

Наступними нормативно-правовими актами, які не можемо залишити поза увагою, є закони України «Про місцеві державні адміністрації» [10] та «Про місцеве самоврядування в Україні» [11]. Аналіз положень Закону України «Про місцеві державні адміністрації» дозволяє виокремити питання, що безпосередньо стосуються сфери соціального захисту населення [10]: 1) до відання місцевих державних адміністрацій належить вирішення питань соціального захисту, зайнятості населення, праці та заробітної плати; 2) місцеві державні адміністрації в межах, визначених законами України, здійснюють на відповідних територіях державний контроль за додержанням законодавства з питань науки, мови, реклами, освіти, культури, охорони здоров'я, материнства та дитинства, сім'ї, молоді та дітей, соціального захисту населення, фізичної культури і спорту; 3) у галузі бюджету місцева державна адміністрація здійснює фінансування підприємств, установ і організацій освіти, культури, науки, охорони здоров'я, фізичної культури і спорту, соціального захисту населення, переданих у встановленому законом порядку в управління місцевій державній адміністрації вищими органами державної влади або органами місцевого самоврядування, що представляють спільні інтереси територіальних громад.

Закон України «Про місцеві державні адміністрації» у ст. 23 [10] встановлює повноваження в галузі соціального захисту населення: 1) реалі- 
зує державну політику в галузі соціального забезпечення та соціального захисту соціально незахищених громадян; 2) створює мережу, забезпечує зміцнення і розвиток матеріально-технічної бази центрів обліку бездомних осіб, закладів соціального захисту населення, підвищення рівня та якості обслуговування в них; 3) розробляє і забезпечує виконання комплексних програм поліпшення обслуговування соціально незахищених громадян, осіб та сімей із дітьми, які перебувають у складних життєвих обставинах, сприяє розвитку послуг.

Закон України «Про місцеве самоврядування в Україні» є одним із базових законів для всієї системи органів місцевого самоврядування. Закон досить великий за обсягом і складний на предмет правового регулювання. Він містить цілу низку норм - принципів, норм матеріального та процесуального права [11]. Питанням повноважень у сфері соціального захисту населення в Законі відведена ст. 34 , у якій до відання виконавчих органів сільських, селищних, міських рад належать такі питання: встановлення власним коштом i завдяки благодійним надходженням додаткових до встановлених законодавством гарантій щодо соціального захисту населення; здійснення контролю за охороною праці, забезпеченням соціального захисту працівників підприємств, установ і організацій усіх форм власності, зокрема зайнятих на роботах зі шкідливими та небезпечними умовами праці, за якістю проведення атестації робочих місць щодо їхньої відповідності нормативно-правовим актам про охорону праці, за наданням працівникам відповідно до законодавства пільг і компенсацій за роботу у шкідливих умовах. Водночас наведене вище не виключає серед делегованих повноважень виконавчих органів сільських, селищних, міських рад їхнього обов'язку щодо надання громадянам, які потребують соціального захисту, безоплатного житла або за доступну для них плату [11]. Отже, доцільно зробити висновок про досить широке коло повноважень органів місцевого самоврядування у сфері соціального захисту населення.

Підбиваючи підсумок проведеного дослідження в частині нормативних засад діяльності Департаменту соціального захисту населення, варто зазначити, що на прикладі Департаменту соціального захисту населення Харківської обласної державної адміністрації наведено широку правову основу діяльності досліджуваного органу державної влади через його подвійну підпорядкованість та велике коло різного роду правовідносин, які потребують урегулювання в повсякденному житті громадян. Серед ключових і далеко не єдиних нормативно-правових актів рівня закону варто виокремити закони України «Про соціальні послуги» та «Про місцеві державні адміністрації» .

\section{Jimepamypa}

1. Фролов Ю.М. Правові засади діяльності вищих навчальних закладів в Україні. Форул права. 2013. № 1. C. 1079-1085. URL: http://nbuv.gov.ua/UJRN/ FP index.htm 2013 1177.

2. Жарова О.П. Правові засади функціонування вищого навчального закладу в Україні. Науковий вісник Міжнародного гуманітарного університету. Сeрія «Юриспрудениія». 2016. Вип. 19. С. 49-52. URL: http://nbuv.gov.ua/UJRN/Nvmgu_jur_2016_19_15.

3. Звіздай О.В. Нормативно-правові засадй розвитку місцевого самоврядування в Україні. Актуальні проблеми державного управління. 2015. № 1. С. 242-249.

4. Конституція України, прийнята на п'ятій сесії Верховної Ради України 28 червня 1996 р. Відомості Верховної Ради України. 1996. № 30. Ст. 141.

5. Ткачук А.Ф. Місцеве самоврядування та децентралізація : практичний посібник. Швейцарсько-український проєкт «Підтрилка децентралізації в Українi-DESPRO». Київ : ТОВ «Софія», 2012. 120 с.

6. Рішення Конституційного Суду від № 3-рп/2012 від 25 січня 2012 р.

7. Про соціальні послуги : Закон України від 19 червня 2003 р. № 966-IV. Відолості Верховної Ради України. 2003. № 45 . Ст. 358.

8. Про соціальні послуги : Закон України від 17 січня 2019 р. № 2671-VIII. Відомості Верховної Ради України. 2019. № 18. С. 5. Ст. 73.

9. Про біженців та осіб, які потребують додаткового або тимчасового захисту : Закон України від 8 липня 2011 р. № 3671-VI. Відомості Верховної Ради України. 2012. № 16. С. 702 . Ст. 146.

10. Про місцеві державні адміністрації : Закон України від 9 квітня 1999 р. № 586-XIV. Відолості Верховної Ради України. 1999. № 20. Ст. 190.

11. Про місцеве самоврядування в Україні : Закон України від 21 травня 1997 р. № 280/97-ВР. Відолості Верховної Ради України. 1997. № 24. Ст. 170.

\section{Анотація}

ШІпарага Ю. I. Нормативно-правові засади діяльності регіонального Департаменту соціального захисту населення: порівняльно-правовий аналіз. - Стаття.

У статті проаналізовано етимологію правової категорії «нормативно-правові засади», окреслено рівні нормативних засад діяльності регіонального Департаменту соціального захисту населення з урахуванням юридичної сили нормативно-правових актів, що врегульовують досліджувані правовідносини. Вказано, що діяльність регіонального Департаменту соціального захисту населення вимагає від держави своєчасного розроблення, ухвалення чи оновлення нормативно-правових засад. Як орган публічної влади Департамент під час реалізації та захисту соціальних прав громадян повинен керуватися як загальноправовими, так і спеціальними принципами діяльності.

Акцентовано увагу на перевагах і недоліках нової редакції Закону України «Про соціальні послуги». Вказані автором позитивні напрацювання законодавців у сфері соціального захисту населення, а саме: 1) чітко визначені на законодавчому рівні суб'єкти системи надання соціальних послуг; 2) у статті 10 Закону «Про соціальні послуги» окреслено основні засади функціонування системи надання соціальних послуг; 3) стали революційними положення статті 15 Закону щодо Реєстру надавачів та отримувачів соціальних послуг; 4) на основі державного стандарту соціальних 
послуг деталізовано порядок їх надання. На підставі аналізу та порівняння положень Закону України «Про соціальні послуги» у редакціях від 2003 року і 2019 року вбачається можливим дійти висновку про всебічний розвиток зазначеного нормативно-правового акта шляхом деталізації ключових положень Закону в останній редакції. Автором звернута увага на наявність широкого кола повноважень органів місцевого самоврядування у сфері соціального захисту населення, що стало передумовою для подвійної підпорядкованості регіонального Департаменту соціального захисту населення. Також вказано на велике коло правовідносин у сфері соціального захисту населення, які потребують відповідного врегулювання.

Ключові слова: Департамент соціального захисту населення, нормативно-правові засади, класифікація, повноваження, соціальні послуги.

\section{Summary}

Shparaga Yu. I. Normatively legal bases of activity of regional Department of social defense of population: comparatively legal analysis. - Article.

The article analyzes the etymology of the legal category "normative and legal principles" and outlines the levels of normative principles of the activity of the regional Department of social protection of the population, taking into account the legal force of normative legal acts that regulate the studied legal relations. It is stated that the activity of the regional Department of social protection of the population requires from the state timely development, adoption or updating of legal bases. As a public authority, the Department in the implementation and protection of social rights of citizens should be guided by both general legal and special principles of activity.

Attention is drawn to the advantages and disadvantages of the new version of the Law of Ukraine "On Social Services". The positive developments of the legislators in the field of social protection of the population, indicated by the author, namely: 1 ) clearly defined at the legislative level the subjects of the system of providing social services; 2) Article 10 of Ukraine "On Social Services" outlines the basic principles of functioning of the system of provision of social services; 3 ) the provisions of Article 15 of the Law on the Register of Providers and Beneficiaries of Social Services became revolutionary; 4) on the basis of the state standard of social services the order of their provision is detailed. Based on the analysis and correlation of the provisions of the Law on Social Services in the 2003 and 2019 editions, it is possible to conclude on the comprehensive development of the specified legal act by detailing the key provisions of the law in the latest wording. The author drew attention to the presence of a wide range of powers of local self-government bodies in the field of social protection of the population, which became a prerequisite for the dual subordination of the regional Department of social protection of the population. There are also a large number of legal relationships in the field of social protection of the population that need to be properly regulated.

Key words: Department of social protection of population, legal framework, classification, powers, social services. 